\title{
Toxicity of phenmedipham and carbendazim to Enchytraeus crypticus and Eisenia andrei (Oligochaeta) in Mediterranean soils
}

\author{
Sonia Chelinho • Xavier Domene • Paolo Campana • \\ Pilar Andrés • Jörg Römbke • José Paulo Sousa
}

Received: 31 July 2013 / Accepted: 20 November 2013 /Published online: 5 December 2013

(C) Springer-Verlag Berlin Heidelberg 2013

\begin{abstract}
Purpose The main objective of the present study was to evaluate the toxicity of two reference chemicals, Carbendazim and Phenmedipham, for the compostworm Eisenia andrei (effects of Carbendazim) and the potworm Enchytraeus crypticus (effects of Phenmedipham) in 12 Mediterranean soils with contrasting soil properties. The observed toxicity was also compared to that obtained for OECD standard soil, used as a control. Materials and methods The soils were selected to be representative for the Mediterranean region and to cover a broad range of soil properties. The evaluated endpoints were avoidance behavior and reproduction. Soils were also assembled in two groups according to their pedological properties.

Results and discussion Toxicity benchmarks (AC50s) obtained for $E$. andrei avoidance behavior in carbendazim-contaminated soils were generally higher for sandy soils with low $\mathrm{pH}$. The
\end{abstract}

Responsible editor: Winfried Schroeder

S. Chelinho $(\bowtie) \cdot$ J. P. Sousa

IMAR-CMA, Department of Life Sciences, Largo Marques de Pombal, University of Coimbra, 3004-517 Coimbra, Portugal

e-mail: sonia.chelinho@iav.uc.pt

J. P. Sousa

e-mail:.jps@zoo.uc.pt

$X$. Domene $\cdot$ P. Andrés

Unit of Ecology, Centre for Ecological Research and Forestry Applications (CREAF), Autonomous University of Barcelona, Cerdanyola del Vallès, 08193 Barcelona, Spain

$\mathrm{X}$. Domene

e-mail: x.domene@creaf.uab.es

P. Andrés

e-mail: Pilar.Andres@uab.cat

P. Campana

Facoltà di Agrária, Università degli Studi di Torino, Torino, Italy

J. Römbke

ECT Oekotoxikologie GmbH, Böttgerstrasse 2-14, 65439 Flörsheim, Germany

e-mail: j-roembke@ect.de toxic effects on the reproduction of the compostworms were similar in the six tested soils, indicating a low influence of soil properties. The avoidance response of E. crypticus towards Phenmedipham was generally highly variable in all tested soils. Even though, a higher toxicity was observed for more acidic soils. The EC50s for reproduction of the latter species varied by a factor of 9 and Phenmedipham toxicity also tended to be increasing in soils with lower $\mathrm{pH}$, except for the soils with extreme organic matter content ( 0.6 and $5.8 \%)$.

Conclusions A soil effect on chemical toxicity was clearly confirmed, highlighting the influence that test soils can have in site-specific ecological risk assessment. Despite some relationships between soil properties and toxicity were outlined, a clear and statistically significant prediction of chemical toxicity could not be established. The range of soil properties was probably narrow to give clearer and more consistent insights on their influence. For the four groups of tests, the toxicity observed for OECD soil was either similar, lower, or generally higher if compared with Mediterranean soils. Moreover, it did represent neither the organic matter content found in Mediterranean soils nor their textural classes.

Keywords Carbendazim · Compost worms · Phenmedipham . Potworms avoidance test $\cdot$ Reproduction test $\cdot$ Soil properties

\section{Introduction}

The increase in ecological relevance of test data is one of the major challenges of soil ecotoxicology (Breitholtz et al. 2006; Kuperman et al. 2009; Van Gestel 2012). For example, most of the soil ecotoxicity data available are still obtained from tests performed using standardized artificial soil, such as the "OECD soil" (OECD 1984) as test substrate. It is a mixture of sand $(70 \%)$, kaolin clay $(20 \%)$, and peat $(10 \%)$, and it has been extensively used mainly because it is easy to prepare and enables inter-laboratory comparisons of test results. One of the major problems of this soil is the fact that its $10 \%$ peat does 
not represent the content neither the type of organic matter of the majority of agricultural soils (European Commission 2005). These concerns lead to new recommendations pointing for the use of a reduced peat content $(5 \%)$, namely within the OECD guidelines (Van Gestel 2012), as well as for the use of natural reference soils (Römbke and Amorim 2004; Kuperman et al. 2009).

In fact, organic matter and other soil properties such as texture can alter the fate and effect of pesticides (Peijnenburg et al. 1999; Sijm et al. 2000; Kördel et al. 2009). Indeed, after chemicals application to soil, the bioavailable fraction for soil organisms, mainly those exposed via soil pore water (Smit and Van Gestel 1998), is dependent on the amount sorbed to soil particles (Van Gestel 2012). The degree of pesticide sorption to soil particles is conditioned not only by pesticide chemical properties but also by the amount and the nature of clay and organic matter (Arias-Estevez et al. 2008). Soil cation exchange capacity (CEC) can also play an important role in the adsorption of weak base pesticides such as carbendazim (Liu et al. 2012).

Therefore, pesticide toxicity data obtained using OECD soil as test substrate cannot be directly extrapolated to field soils (Kördel et al. 2009) since misleading toxicity estimations can take place (Römbke and Amorim 2004).

Consequently, the selection and use of natural soils in soil ecotoxicological testing has been increasing (Kördel and Römbke 2001; Van Gestel and Weeks 2004; Kuperman et al. 2009). Due to the broad range of potential test soils, some approaches included the selection of a small set of representative and well characterized soils, from different European ecoregions. This was the case in for the selection of six "EuroSoils" (Kuhnt and Vetter 1999), the "SIM-soils" (Römbke and Amorim 2004), the "REFESOLS" (in Germany; Kördel et al. 2009), the "Polish soils" (Maliszewska-Kordybach et al. 2008), the "Nordic Reference Soils" (Tibberg 1998), and the "Mediterranean Soils" (Chelinho et al. 2011).

Moreover, in pesticide registration, fate and effects data are mainly obtained in Central Europe and North America (Autio et al. 2004) and extrapolated to other climatic regions, such as the Mediterranean. However, Mediterranean regions have specificities that can influence the environmental behavior of pesticides (e.g., their persistence, degradation rate, and mobility) and, consequently, their bioavailability to ecological receptors (Daam et al. 2011; Ramos et al. 2000). Those include the climate, with higher mean temperatures, solar radiation, and lower mean annual precipitation than Central and Northern Europe, but with more frequent extreme precipitation/dryness phenomena (Ramos et al. 2000; Daam et al. 2011). In addition, the farming practices include the cultivation of different crops, in smaller farms, with the application of different categories and amounts of pesticides (Ramos et al. 2000; Daam et al. 2011). Therefore, it is necessary to refine ecological risk assessment, e.g., evaluating toxic effects using local soils with different pedological characteristics.

Recently, some efforts have been made to provide information on the influence of soil properties in chemical toxicity, using a set of natural soils and standard ecotoxicological tests species like compostworms (Römbke et al. 2006, 2007), enchytraeids (Amorim et al. 2005a, b, c; Kuperman et al. 2006), springtails (Amorim et al. 2005d; Römbke et al. 2006, 2007; Domene et al. 2010, 2012), and plants (Römbke et al. 2006, 2007; Rocheleau et al. 2010).

The uncertainty associated with extrapolation of toxicity data from artificial to field soils is thus being reduced and through these and other contributions, like for example the correction of toxicity data for bioavailability of metals among soils (spiked and field contamination) (Checkai et al., submitted to IEAM). However, further tests, covering more soil types and more chemicals are needed (Römbke et al. 2007) to make more reliable predictions on the conditioning effects that soil properties can exert on the responses of organisms to chemicals.

In the present contribution, 12 Mediterranean soils, selected in order to cover a broad range of soil properties, and OECD artificial soil (OECD 1984) as control were used as test substrates in standardized avoidance and reproduction tests.

The toxicity of two reference chemicals, carbendazim and phenmedipham, was assessed, respectively, for the earthworm Eisenia andrei and the enchytraeid Enchytraeus crypticus. The suitability of the soils as standard test substrates for these species has been previously assessed (Chelinho et al. 2011).

Our main goals were (1) to evaluate the toxicity of the reference chemicals to the two oligochaete species in the tested-soils, (2) to study the influence of soil properties on the observed toxicity, and (3) to compare chemical toxicity on natural and OECD soils.

\section{Materials and methods}

\subsection{Test soils}

The set of test soils included four soils from the Alentejo region (southern Portugal), five soils from Cataluña (northeastern Spain), and three soils from Liguria (north-western Italy). Their pedological characteristics were analyzed by DRAEDM-Portugal, according to standard methods previously described (Chelinho et al. 2011). Standard artificial OECD soil (OECD 1984) was used as a control.

All soils were sieved ( $5 \mathrm{~mm}$ mesh) and defaunated through two freeze-thawing cycles. The moisture was adjusted to 40 $60 \%$ of the corresponding maximum water holding capacity with deionized water, except for the soils with higher clay content ( $\mathrm{Br}$ and Gra). For these, this value was reduced to about $35-45 \%$ to avoid soil soaking.

\subsection{Test organisms}

The selected species, E. andrei and E. crypticus, are representatives of epigeic lumbricid and enchytraeid Oligochaeta 
(Jänsch et al. 2005; Westheide and Graefe 1992). They play an important role in the soil ecosystem and are standard organisms of ecotoxicological studies (Jänsch et al. 2005). Both test organisms were obtained from laboratory cultures that were maintained as previously described by Natal-da-Luz et al. (2008) for E. andrei and Chelinho et al. (2011) for E. crypticus .

\subsection{Test chemicals}

For both avoidance and reproduction tests with enchytraeids, the soils were spiked with an aqueous solution of the herbicide Phenmedipham (CAS 13684-63-4; commercial formulation Betosyp; STÄHLER AGROCHEMIE; $157 \mathrm{~g}$ a.i./L) in the following nominal concentrations: $1,3,9,27$, and $81 \mathrm{mg}$ a.i./kg of dry soil. This herbicide is not very soluble in water, relatively immobile, and low to moderately persistent in soil. Despite this, under acidic conditions, the degradation rates are lower and the compound may persist longer. Also, its primary degradation metabolite, methyl-3-hydroxylphenylcarbamate, showed to have higher mobility in soil (EPA 2005).

The fungicide carbendazim (CAS 10605-21-7; commercial formulation Derosal, AventisCropScience Portugal, 60\% a.i.) was used for the assays with earthworms in the following nominal concentrations: $1,1.78,3.16,5.62$, and $10 \mathrm{mg}$ a.i. $/ \mathrm{kg}$ of dry soil (avoidance tests) and 0.58, 1.78, 3.16, and $5.62 \mathrm{mg}$ a.i. $/ \mathrm{kg}$ of dry soil (reproduction tests). Carbendazim has low water solubility and can persist in soil in an immobilized state due to interactions with soil colloids (Berglöf et al. 2002). The soil adsorption seems to be inversely correlated to the soil pH (Paszko 2012).

For both chemicals, concentrations were selected based on the results of range-finding tests (data not shown).

For all tests, different proportions of the stock solutions were diluted with deionized water to obtain the outlined nominal concentrations.

\subsection{Experimental procedure}

\subsubsection{Tests with E. andrei}

For avoidance tests, the procedure was based on ISO 17512 (ISO 2008). For each soil, ten adult earthworms were placed in the middle line of a test box filled with the uncontaminated control soil in one side and the contaminated soil on the other side. Five replicates per combination were tested. After $48 \mathrm{~h}$ of exposure, the number of organisms on each side was determined. Animals found under the middle line were counted as 0.5 for each side. Dual-control tests (the same soil type on both sections of the test box) were also performed to check for the random distribution of the animals (ISO 2008). Due to a limited amount of available soil, $\mathrm{Br}$, It3, and It4 soils were not tested (Table 1).

The reproduction of $E$. andrei in carbendazim-contaminated soils was assessed for OECD artificial soil plus five natural soils: Luv, It2, It4, Por, and Pra (Table 1). Background information on avoidance and reproduction performance of this species in the 12 Mediterranean uncontaminated soils showed that, for some of the soils, pedological properties caused a strong avoidance response and impaired successful reproduction (Chelinho et al. 2011). Although in this previous study, the reproduction rates in It3 accomplished the ISO validity criteria, due to the reduced amount of available soil, the toxicity test could not be carried out. The tests were performed following the ISO 11268-2 guideline (ISO 2012). Ten weighted clitellate adults were introduced in $500 \mathrm{~g}$ (d.w.) of control or contaminated soil. Four replicates were used. Ground cow dung was added as food supply. After 28 days of exposure, living adults were removed and weighted again. The cocoons laid by the adults hatched during the next 28 days, and after this period, the test vessels were placed in a water bath at $60{ }^{\circ} \mathrm{C}$ to force the juveniles to come to the soil surface.

\subsubsection{Tests with E. crypticus}

In the avoidance tests with enchytraeids, the same principle of the tests with earthworms was applied but was based on the methodology reported by Amorim et al. (2005a). However, in our study, smaller cylindrical plastic vessels $(6 \mathrm{~cm}$ diameter and $4 \mathrm{~cm}$ height) and $20 \mathrm{~g}$ (d.w.) of soil on each side were used instead. Based on the experience gathered from the tests initially conducted, where a high variation in the avoidance response was observed (see Section 3.3.1.), it was decided not to perform the avoidance tests with Pra and Riu soils.

The toxicity of Phenmedipham on E. crypticus reproduction was assessed for all natural soils and OECD artificial soil, according to the guideline ISO 16387 (ISO 2004). This guideline was originally designed for testing with Enchytraeus albidus, but other enchytraeid species, like E. crypticus, are listed as an alternative. Due to the smaller size and shorter reproductive cycle of the latter species, the test duration was reduced to 28 days. In this case, $20 \mathrm{~g}$ (d.w.) of soil was used and the adults were kept in the vessels until the end of the test. For each vessel, ten clitellate enchytraeids were placed in the soil. Four replicates were used. As food supply, finely ground rolled oats was added. Weekly, when necessary, additional food and water were added. At the end of the test, the number of enchytraeids was assessed after fixation, staining, and wet sieving (mesh width of $103 \mu \mathrm{m}$ ), a technique kindly shared by Dr. Roman Kuperman from US Army. In brief, the wet sieving consisted in filling the test vessel with water, gently stirring and putting the liquid fraction into the sieve, rinse the content of the sieve, and transfer it to a counting tray (Petri dish). This procedure was repeated until the stirred water became clear. The soil fraction remaining in the test vessel (mainly the sand fraction) was transferred to the sieve and checked for the presence of enchytraeids.

All tests were conducted at $20 \pm 2{ }^{\circ} \mathrm{C}$ with a $16: 8$ (light/ dark) photoperiod. Both $\mathrm{pH}$ and moisture were measured at the beginning and end of the tests (an extra replicate, without 


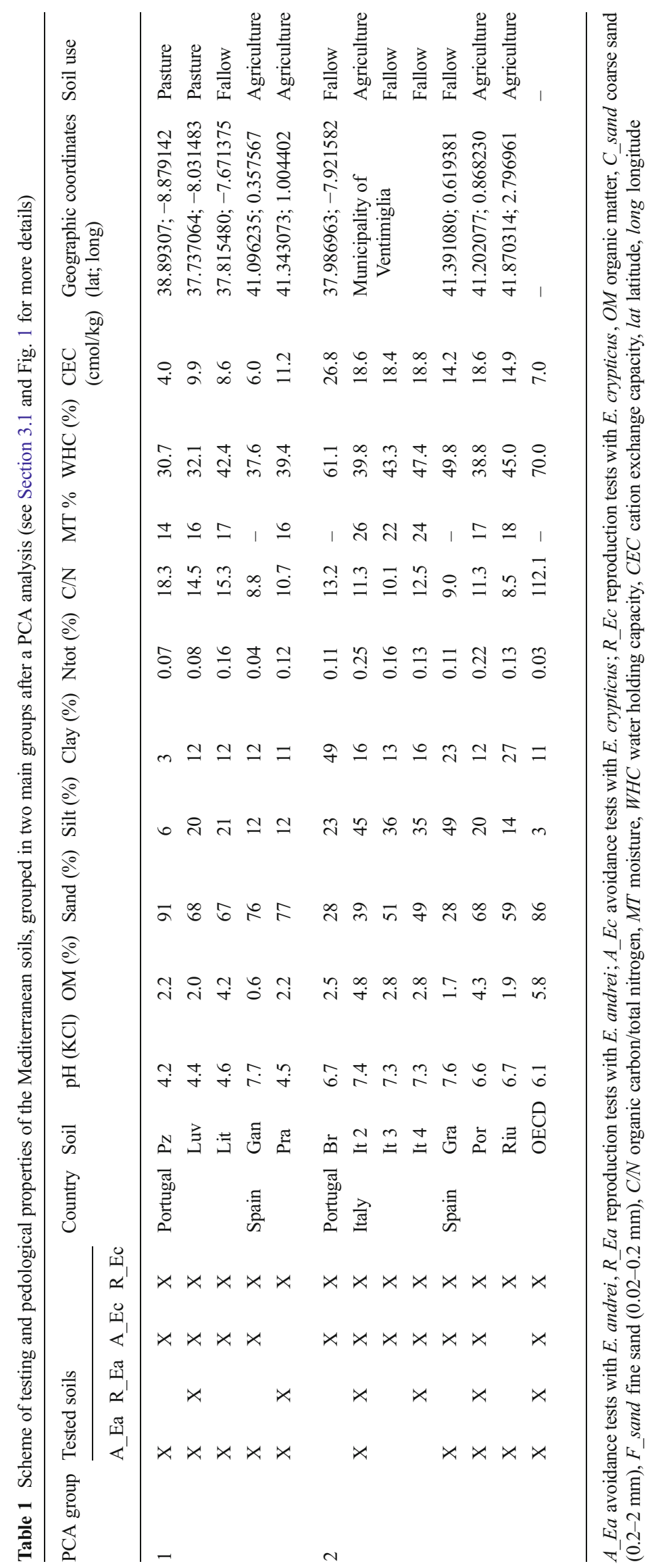


organisms, was used for $\mathrm{pH}$ and moisture check, in the case of reproduction tests with E. crypticus).

\subsection{Statistics}

\subsubsection{Avoidance tests}

For both test species and for all tested soils, statistical differences in the distribution of test organisms were analyzed using Fisher's exact test (Zar 1999). With this test, comparisons between the obtained distribution and a theoretical distribution (assuming a "no avoidance" situation, the "null hypothesis") were performed. For avoidance tests, a one-tailed distribution was used (a response towards the contaminated soil was expected), while for dual-control assays, a two-tailed test was used (a random distribution of the organisms between the two soil compartments was expected) (Natal-da-Luz et al. 2008). Regarding enchytraeid tests, the total number of individuals was corrected using the mortality rate obtained in the dual tests.

According to ISO 17512 (ISO 2008), the percentage of avoidance $(A)$ was calculated using the expression $A=((C-$ $T) / N) \times 100$, where $A=\%$ avoidance, $C=$ number of individuals in the control soil, $T=$ number of individuals in the test soil, and $N=$ total number of individuals.

Since the objective was to evaluate the influence of soil properties on chemical toxicity, one modification was made: a negative response (preference) towards the chemical was not considered as zero, i.e., originating a negative value of $A$.

The concentrations causing 50\% avoidance behavior (AC50s) were calculated using probit analysis with PriProbit Software (Sakuma 1998). The applied model was the "preference model," assuming, for a two-choice system, that $50 \%$ of animals are in each side of the test vessels (no avoidance). As this software required an increasing response, the total number of animals in the control side (uncontaminated soil) was used as input data.

\subsubsection{Reproduction tests}

For no-observed-effect-concentration (NOEC) calculations, data were analyzed for normality (KolmogorovSmirnov test) and for variance homogeneity (Levene's test). Whenever heterogeneity was detected, a square root transformation was applied. A one-way ANOVA followed by post hoc comparisons with the control (Dunnets' test) was performed. Statistica 7.0 (StatSoft Inc 2004) software was used.

The EC50s for reproduction (and the associated 95\% confidence intervals) were calculated using non-linear regressions, according to Stephenson et al. (2000). The best fitting models, i.e., the lines generated most closely to the data points, with smallest variances and a more random distribution of residuals included Gompertz (1), Hormesis (2), Linear (3), and Logistic (4) models (Environment Canada 2007).

$Y \quad$ Number of juveniles

logconc The log-transformed exposure concentration

$x \quad$ Estimate of $50 \%$ effect concentration

$h \quad$ Hormetic effect (estimated between 0.1 and 1)

$b \quad$ Scale parameter (estimated between 1 and 4)

$Y=c \times \exp \left((\log (0.5)) \times\left(\log \operatorname{conc} / x^{\wedge} b\right)\right.$

$Y=(c \times(1+h \times \log \operatorname{conc})) /\left(1+((0.5+h \times \log \operatorname{conc}) / 0.5) \times(\log \operatorname{conc} / x)^{\wedge} b\right)$

$Y=((-c \times 0.5) / x) \times \log c o n c+c$

$Y=\mathrm{c} /\left(1+(\log \operatorname{conc} / x)^{\wedge} b\right)$

\subsubsection{Influence of soil properties on toxicity data}

The Mediterranean soils were grouped according to their pedological properties using a principal component analysis (PCA) in which the soil parameters were centered and standardized. This analysis was performed using CANOCO for Windows software (Ter Braak and Smilauer 2002). As the soils were separated in two main groups, for each set of tests (avoidance or reproduction with $E$. andrei or E. crypticus), whenever possible, the mean of the derived EC50s or AC50s was calculated for each one of the two groups to establish possible relationships between soil properties and toxicity parameters.

The AC50 derived for avoidance tests with $E$. andrei and carbendazim in Gan soil was not included in the latter analysis, as it was the unique soil, among ten, where a dose response was not observed. Moreover, previous experiments showed that this soil may not be suitable to this species (see Chelinho et al. 2011).

\section{Results}

3.1 Mediterranean test soils and their ordination according to pedological properties

The tested soils covered a wide range of soil properties, with soil $\mathrm{pH}$ ranging from 4.2 to 7.7 and organic matter content 
ranging from 0.6 to $4.8 \%$, and the ordination of Mediterranean soils according to their pedological properties is shown on Fig. 1. Axis 1 of the PCA biplot separated soils in two main groups (51.6\% of total variation explained). Soils located on the positive side of axis 1 were basically sandy soils, collected in Portugal and Cataluña and were included in group $1(\mathrm{Pz}$, Luv, Lit, Gan, and Pra; Fig. 1). All the other soils, located in the negative side of the axis were included in group 2 (with Italian soils - It1, It2, and It3 - plus Gra, por, and Riu from Spain and Br from Portugal) and had higher values of silt, clay, pH, CEC, and WHC (Fig. 1). Axis 2 (23.2\% of total variation explained) separated soils according to their organic matter content and total N (Fig. 1).

\subsection{Effects of carbendazim-contaminated soils on $E$. andrei}

\subsubsection{Avoidance tests}

Earthworm avoidance response towards carbendazimcontaminated soil showed a clear dose-response in all soils tested, except Gan soil (Fig. 2). Moreover, no mortality was recorded. Results from dual-control tests revealed a homogeneous distribution of the organisms on both sections (data not shown).

The calculated AC50s ranged from $1.3 \mathrm{mg} / \mathrm{kg}$ for Lit and It 2 to $9.4 \mathrm{mg} / \mathrm{kg}$ for Gan (Table 2). For this latter soil, the response was highly variable, e.g., in the concentration $5.62 \mathrm{mg} / \mathrm{kg}$, the second highest tested, more organisms were found in the contaminated side (Fig. 2). The derived AC50 for OECD artificial soil was the second highest $(3.9 \mathrm{mg} / \mathrm{kg}$, Table 2$)$ of the ten tested soils and was within the range of results obtained for Pz and Pra soils (3.8 and $3.6 \mathrm{mg} / \mathrm{kg}$, respectively, Table 2 ). In Luv, Lit, It 2, and Riu soils, the lowest concentration tested $(1 \mathrm{mg} / \mathrm{kg})$ caused more than 25\% avoidance (Fig. 2). In all soils, except Gan, the second highest concentration tested $(5.62 \mathrm{mg} / \mathrm{kg})$, caused more than $60 \%$ avoidance. In Luv, Lit, and It 2 soils, at the highest concentration $(10 \mathrm{mg} / \mathrm{kg})$, the contaminated soil was less avoided than in the previous one (5.62 mg/kg; Fig. 2).

\subsubsection{Reproduction tests}

The effects of carbendazim in $E$. andrei juvenile production are presented in Fig. 3.

The ISO validity criteria were achieved in all soils, except in Por, where a variation coefficient of $34 \%$ was observed. A consistent decrease in the number of $E$. andrei juveniles was observed along the carbendazim concentration gradient. Their strong effects did not vary greatly between Mediterranean and OECD soils (Fig. 3). Indeed, the NOECs were all equal or lower than $0.58 \mathrm{mg} / \mathrm{kg}$ and the second concentration tested ( $1 \mathrm{mg} / \mathrm{kg}$ ) caused a severe reduction in juvenile production, since the EC50s varied between 0.73 and $1.27 \mathrm{mg} / \mathrm{kg}$ (Table 3).

The comparison of both reproduction and avoidance parameters, (only five comparisons were possible) show that, in all soils, except It2, the AC50s (Table 2) were more than two times higher than reproduction EC50s (Table 3).

\subsection{Effects of phenmedipham-contaminated soils to $E$. crypticus}

\subsubsection{Avoidance tests}

A low mortality $(1.5 \pm 2.8 \%)$ was observed in all tests. As happened with earthworms, dual-control tests showed a homogeneous distribution of the organisms on both sections (data not shown).

A dose response was observed in the avoidance towards Phenmedipham contamination in most of the soils tested, being more evident in Pz and OECD soils (Fig. 4). However, if compared to the responses of E. andrei towards carbendazim, the enchytraeids' response was less pronounced (Figs. 2 and 4).
Fig. 1 Principal component analysis biplot showing the different clustering of test soils (points) according to their pedological properties (arrows) in group 1 (full circle) and group 2 (dashed circle)

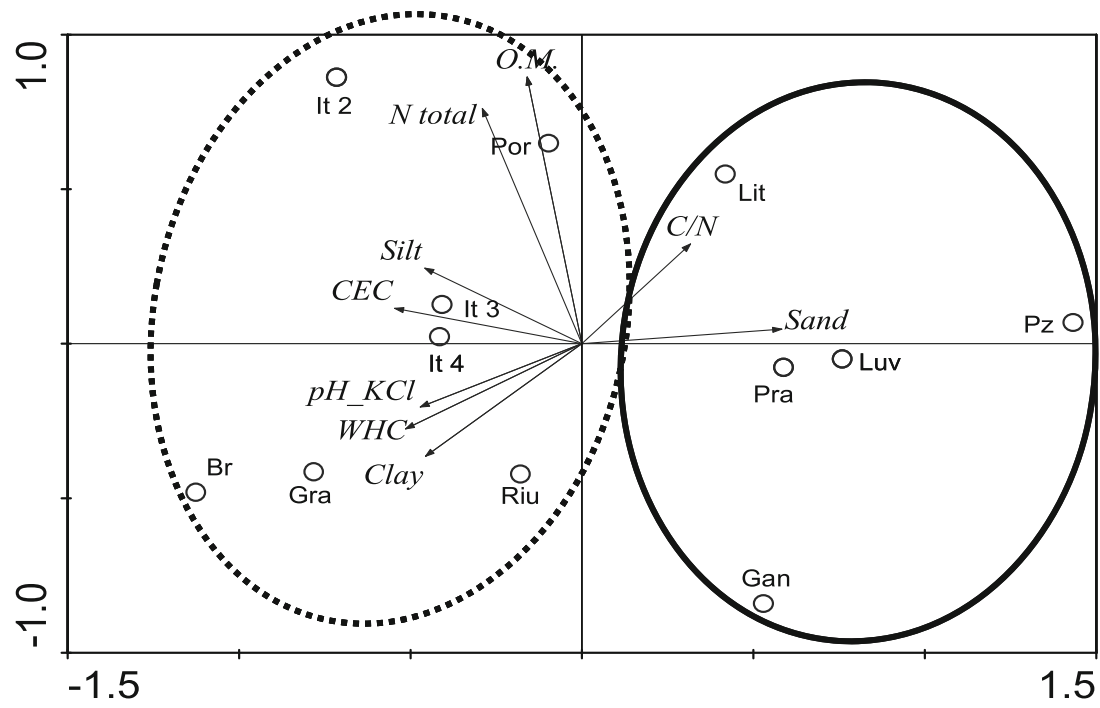



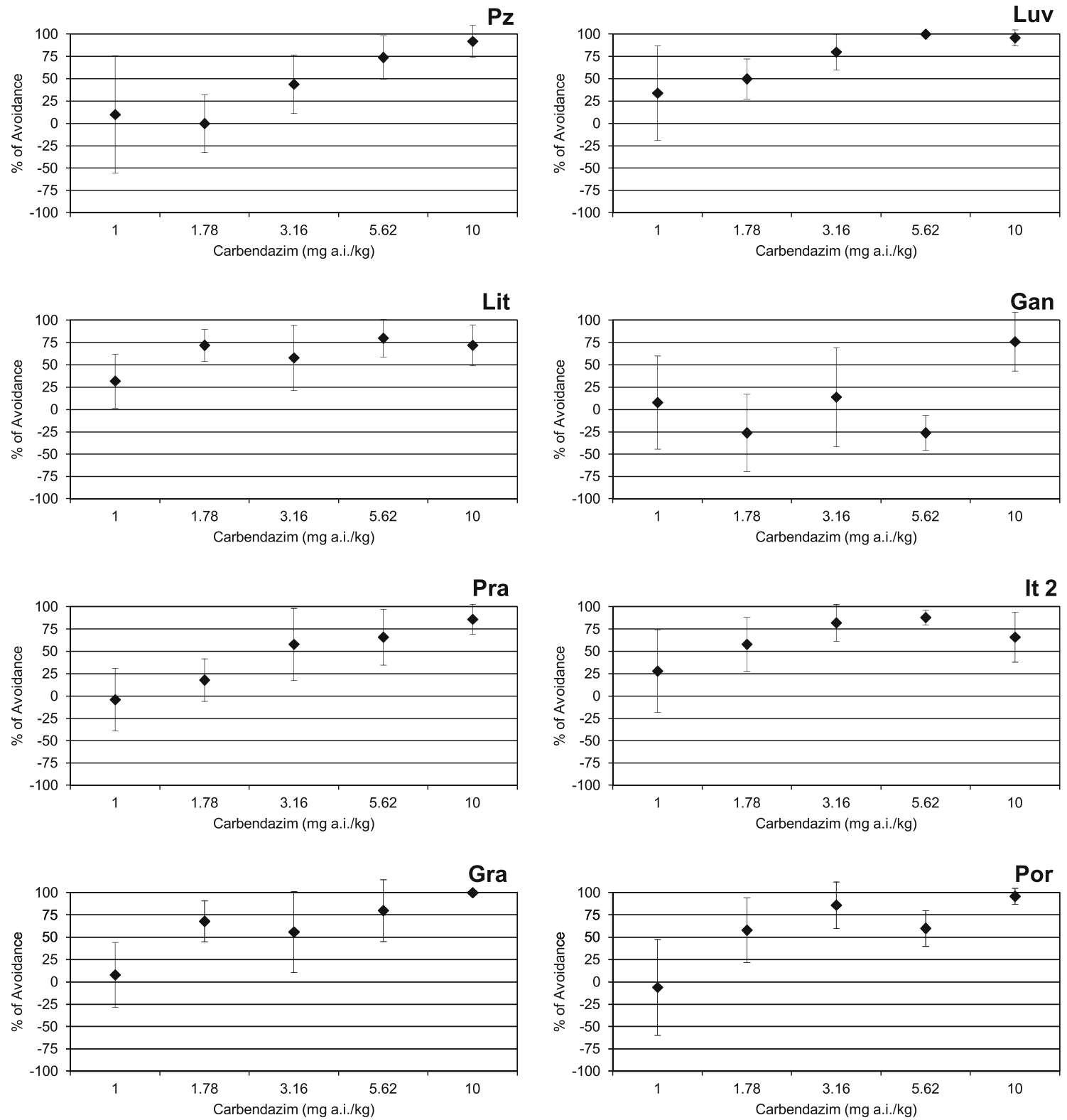

Riu
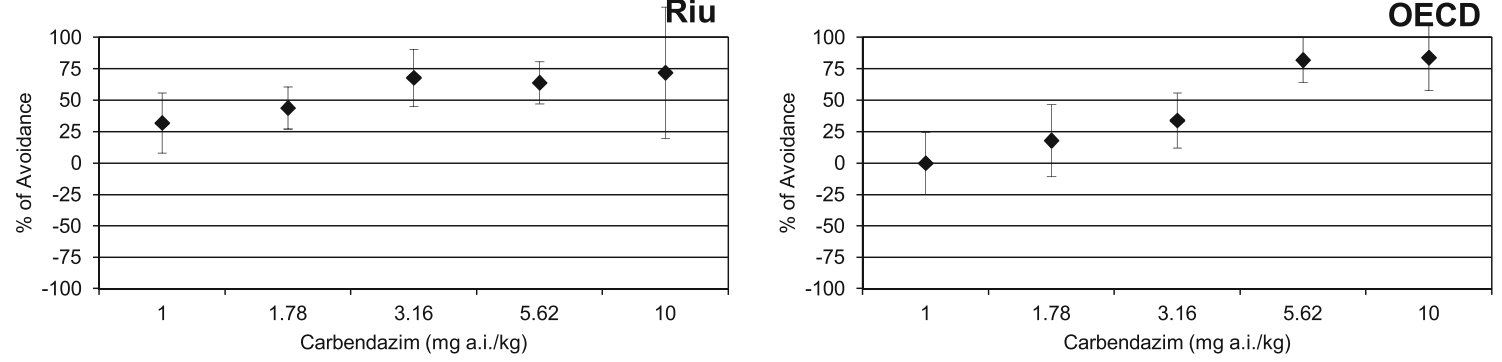

Fig. 2 Avoidance response of E. andrei (average \pm standard deviation) to eight Mediterranean soils plus artificial OECD soil contaminated with Carbendazim. Results reflect the choice between control and contaminated soil

In most soils, no avoidance occurred at the lowest concentration tested $(1 \mathrm{mg} / \mathrm{kg})$, in opposition to $\mathrm{Br}$, Gan, and Gra soils, where a strong avoidance response was already observed at this concentration $(60,44$, and $71 \%$, respectively; Fig. 4).
This high variation in the avoidance response often impaired the calculation of AC50s (for three soils) and/or of the respective confidence limits (for eight soils) (Table 4). Results show a low toxicity of phenmedipham in Italian soils with AC $50 \geq 72 \mathrm{mg} / \mathrm{kg}$, a moderate toxicity in Luv and Lit soils 
Table 2 AC50 values (milligrams a.i. per kilogram) for avoidance of Mediterranean soils contaminated with Carbendazim by $E$. andrei

\begin{tabular}{ll}
\hline Soil & AC50 (mg a.i/kg) \\
\hline Pz & $3.8(2.7-4.8)$ \\
Luv & $1.5(1-2.1)^{\mathrm{a}}$ \\
Lit & $1.3(0-2.6)^{\mathrm{a}}$ \\
Gan & $9.4(\text { n.d. })^{\mathrm{a}}$ \\
Pra & $3.6(2.4-4.8)$ \\
Gra & $2.1(1.3-2.8)$ \\
Por & $2.2($ n.d. $)$ \\
Riu & $2.2(0.3-4.1)^{\mathrm{a}}$ \\
OECD & $3.9(2.6-5.1)$ \\
\hline
\end{tabular}

Data in brackets correspond to the $95 \%$ confidence intervals n.d. values not determined

${ }^{\mathrm{a}}$ Last concentration eliminated from calculations

(AC50 values of 39.5 and $30.9 \mathrm{mg} / \mathrm{kg}$, respectively) and a high toxicity in $\mathrm{Pz}(\mathrm{AC} 50=19.1 \mathrm{mg} / \mathrm{kg})$ and in OECD artificial soil $($ AC50 $=14.2 \mathrm{mg} / \mathrm{kg})($ Table 4$)$.

\subsubsection{Reproduction tests}

The effects of phenmedipham in enchytraeids reproduction are shown in Fig. 5. The validity criteria were fulfilled in all
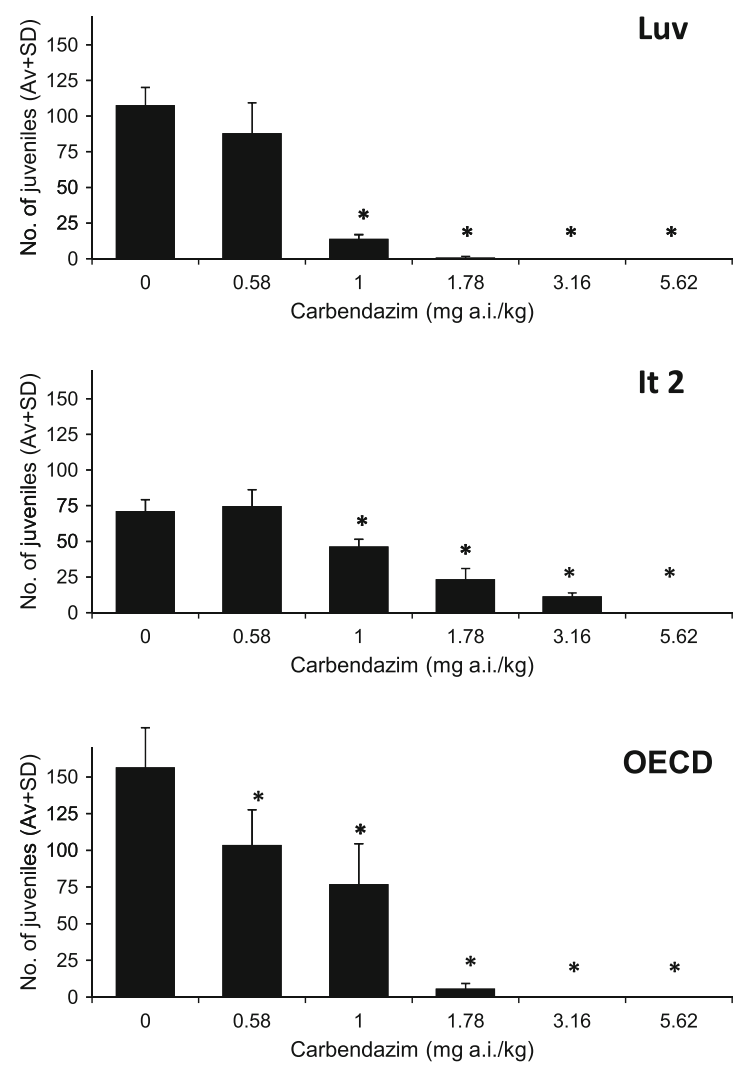

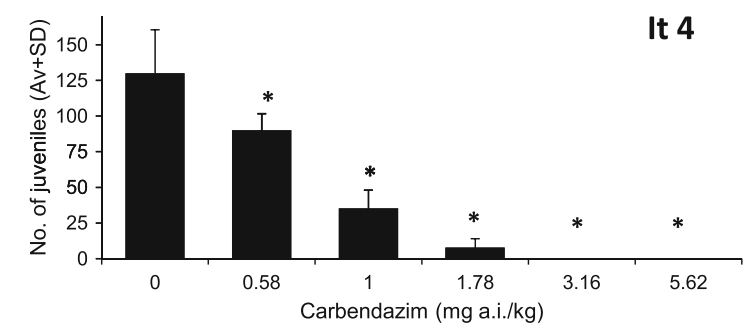

tests. In these tests, the adults could not be consistently distinguished from juveniles in many soils. However, the remaining validity criteria (coefficient of variation lower than $50 \%$ and more than 100 juveniles in the control) were fulfilled in all tests. Like in the avoidance tests, a dose-response relationship was observed, although more clearly in $\mathrm{Pz}, \mathrm{Gan}, \mathrm{Pra}, \mathrm{Br}$, Por, and OECD soils (Fig. 5).

The derived EC50s varied by a factor of approximately 9 (between $3.8 \mathrm{mg} / \mathrm{kg}$ in Gan and $32.8 \mathrm{mg} / \mathrm{kg}$ in It 2; Table 4). The value obtained for OECD soils was of $29.2 \mathrm{mg} / \mathrm{kg}$, the second highest of the 13 soils tested. The NOECs varied between $<1 \mathrm{mg} / \mathrm{kg}$ (Luv and Gan) and $27 \mathrm{mg} / \mathrm{kg}$ (Riu). Results also show that AC50s were higher than EC50s, except for Pz and OECD soils. It should be noticed, however, that no comparisons could be made for five soils, due to the lack of AC50s (Table 4).

\subsection{Influence of soil properties on test results}

The means of the derived EC50s/AC50s for the two groups of soils are shown in Fig. 6. For earthworms and carbendazim, the average for the EC50s was similar, while the average for AC50s was higher for group 1 (sandy soils), although in the latter case the standard deviation was quite high. This was a result of the derived AC50 for Gan soil ( $9.4 \mathrm{mg} / \mathrm{kg}), 2.5$ times higher than the second highest AC50 derived for natural soils of group 1 (3.8 mg/kg for Pz soil; Fig. 6a).

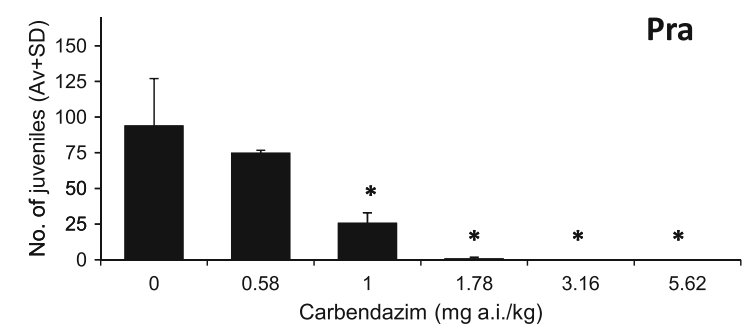


Table 3 EC50 values for reproduction of E. andrei in Mediterranean soils contaminated with Carbendazim. The NOECs for reproduction, the model that best fitted the data, and the corresponding $R^{2}$ are also included

\begin{tabular}{lllll}
\hline Soil & NOEC & EC50 & $R^{2}$ & Model \\
\hline Luv & 0.58 & $0.73(0.67-0.81)$ & 0.96 & Logistic \\
Pra & 0.58 & $0.79(0.68-0.93)$ & 0.91 & Logistic \\
It 2 & 0.58 & $1.27(1.10-1.47)$ & 0.95 & Hormesis \\
It 4 & $<0.58$ & $0.74(0.64-0.84)$ & 0.93 & Logistic \\
Por & 0.58 & $0.89(0.67-1.18)$ & 0.81 & Logistic \\
OECD & $<0.58$ & $0.89(0.73-1.08)$ & 0.92 & Gompertz \\
\hline
\end{tabular}

Data in brackets correspond to the $95 \%$ confidence intervals. All data are expressed as milligrams a.i. per kilogram

The differences in the average EC50s/AC50s between groups 1 and 2 were stronger for enchytraeids and phenmedipham. For avoidance tests, the mean AC50s for sandy soils (group 1) was found to be two times lower than the unique value available within group 2 (It 3 soil; Fig. 6b). The same pattern was observed for reproduction tests, as the value for the group of sandy soils (group 1) was also lower (1.6 times) than for group 2 (Fig. 6b).

\section{Discussion}

\subsection{E. andrei avoidance behavior towards} carbendazim-contaminated soils

Carbendazim and also benomyl (the latter rapidly converts to the former by hydrolysis; Berglöf et al. 2002) have been used as reference chemicals, using OECD soil as test substrate, to test the suitability of earthworms avoidance tests as screening tools in soil risk assessment (e.g., Hund-Rinke and Wiechering 2001; Garcia et al. 2008; Natal-da-Luz et al. 2008).

In the present study, in OECD soil, the concentration $1 \mathrm{mg} /$ $\mathrm{kg}$ caused no avoidance, while at $10 \mathrm{mg} / \mathrm{kg}$, more than $80 \%$ of the earthworms avoided contaminated soil. These results are in accordance with the ones found for benomyl by HundRinke and Wiechering (2001). Slightly different results were reported by Natal-da-Luz et al. (2008) for carbendazim in OECD soil: E. andrei significantly avoided both concentrations of 1 and $10 \mathrm{mg} / \mathrm{kg}$.

In all Mediterranean tested soils, except Gan, animals perceived the increasing concentrations of Carbendazim and also showed a clear dose-avoidance response.

The extremely variable behavior in Gan soil was probably due to its extreme texture and low organic matter content that may have worked as additional stress factors to the compostworms besides the chemical.

Previous studies (in which this Gan soil was combined with other natural soils) indicated it may not be suitable to $E$. andrei (Chelinho et al. 2011). Despite the fact that, in the present study, the control and test soils were the same, their pedological properties, falling out of the tolerance limits of the test species, may have masked toxicity, as animals could not perceive the contamination gradient.

If compared with OECD soil, the avoidance behavior in the Mediterranean soils was similar, but the dose response was mostly less pronounced. For example, the lowest concentration tested (1 mg/kg carbendazim) caused no avoidance response (in five soils) or less than $34 \%$ avoidance (in four soils); in opposition, the last concentration $(10 \mathrm{mg} / \mathrm{kg}$ Carbendazim) caused more than $86 \%$ of avoidance in five (of nine) soils.

The decrease in the avoidance response observed at the highest concentration (10 mg/kg Carbendazim), if compared to the previous ( $5.62 \mathrm{mg} / \mathrm{kg}$ Carbendazim), for Luv Lit and It2 soils could be due to earthworm immobilization in the treated soil provoked by the contaminant. A similar observation was reported by Natal-da-Luz et al. (2008): E. andrei avoidance response was stronger at $10 \mathrm{mg} / \mathrm{kg}$ of carbendazim than at $100 \mathrm{mg} / \mathrm{kg}$ in OECD artificial soil.

Concerning the influence of soil properties on avoidance behavior, results indicated a clear influence of soil properties as the AC50s varied by a factor of 7 (or 3, if the value for Gan soil is excluded, see Section 2.5.3).

According to the mean AC50s for the two groups of soils defined by PCA analysis, toxicity was lower (by 30\%) in sandy soils, with lower $\mathrm{pH}$, silt, clay, CEC, and WHC (Fig. 6a). This might be related with the higher adsorption of carbendazim in acid conditions previously reported by other authors (Ellis et al. 2007; Paszko 2012), which can lead to decreased concentration in soil pore water (Liu et al. 2012), one of the routes of exposure for earthworms. The value of AC50-derived OECD soil was similar to those derived for $\mathrm{Pz}$ and Pra, all having in common a sandy texture and a $\mathrm{pH}$ equal or lower than 6.1. Higher organic matter and clay contents have also been referred to increase carbendazim sorption in soils (Dios Cancela et al. 1992; Berglöf et al. 2002; Ellis et al. 2007). However, conditioning effects of these soil properties were not confirmed in the present study. In fact, avoidance data obtained suggest a positive influence of low $\mathrm{pH}$ and sandy texture in the decrease of carbendazim toxicity.

\subsection{Reproduction of $E$. andrei in carbendazim-contaminated soils}

The negative effects of carbendazim on the reproduction of earthworms have been widely investigated, although most of the data were obtained from tests where the original (or modified) OECD artificial soil was used as test substrate (e.g., Van Gestel et al. 1992; Ellis et al. 2007; Garcia et al. 2008). In the present study, the toxicity observed in OECD soil ( $\mathrm{NOEC}<0.58$ and EC50 of $0.89 \mathrm{mg} / \mathrm{kg}$ ) was similar to the 

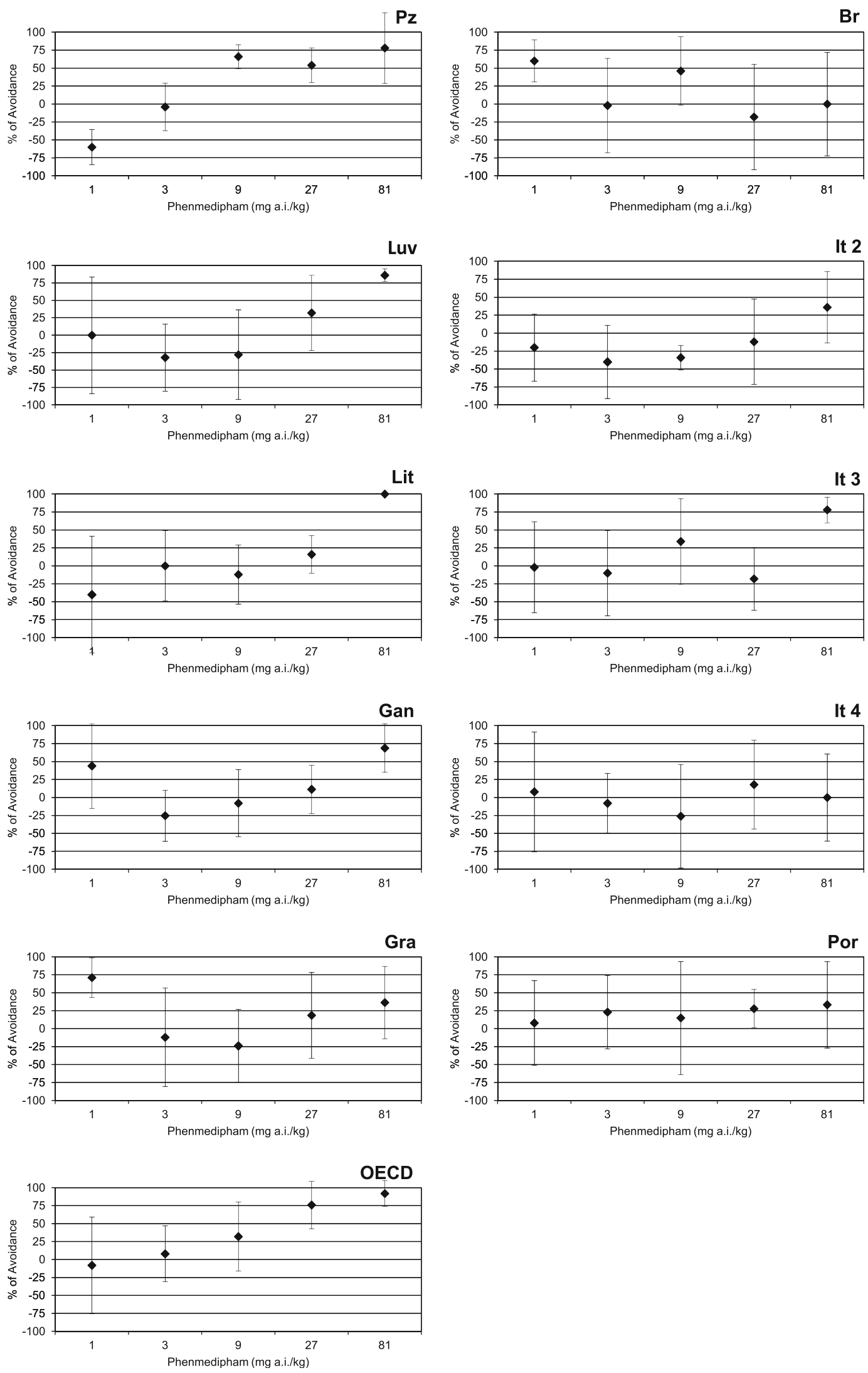

Fig. 4 Avoidance response (average \pm standard deviation) of E. crypticus to ten Mediterranean soils plus OECD artificial soils contaminated with Phenmedipham. Results reflect the choice between control and contaminated soil 
Table 4 Toxicity values for reproduction (EC50) and avoidance (AC50) of E. crypticus in Mediterranean soils contaminated with Phenmedipham. The NOECs for reproduction, the model that best fitted the reproduction data, and the corresponding $R^{2}$ are also included

\begin{tabular}{llllll}
\hline \multirow{2}{*}{ Soil } & \multicolumn{2}{l}{ Reproduction } & \multicolumn{2}{l}{ Avoidance } \\
\cline { 2 - 4 } & NOEC & EC50 & $R^{2}$ & Model & AC50 \\
\hline Pz & 9 & $24.9(13.1-47.7)$ & 0.64 & Gompertz & $19.1($ n.d.) \\
Luv & $<1$ & $14.0(10.3-19.0)$ & 0.87 & Hormesis & 39.5 (n.d) \\
Lit & 9 & $27.5(19.9-37.7)$ & 0.74 & Hormesis & $30.9(20.6-50.7)$ \\
Gan & 1 & $3.8(2.4-5.9)$ & 0.85 & Logistic & 55 (n.d.) \\
Pra & 9 & $10.5(5.0-20.3)$ & 0.49 & Linear & n.t. \\
Br & 3 & $26.8(21.7-33.1)$ & 0.91 & Hormesis & n.d. \\
It 2 & 9 & $32.8(20.9-51.4)$ & 0.68 & Hormesis & $>81$ (n.d.) \\
It 3 & 3 & $17.3(7.1-42.1)$ & 0.57 & Gompertz & 71.5 (n.d.) \\
It 4 & 9 & $26.3(6.7-27.8)$ & 0.72 & Hormesis & $>81$ (n.d.) \\
Gra & 9 & $26.8(21-34.8)$ & 0.56 & Hormesis & n.d. \\
Por & 3 & $26(18.9-36.2)$ & 0.82 & Hormesis & n.d. \\
Riu & 27 & $>27<81$ & - & - & n.t. \\
OECD & 1 & $29.2(20.4-42.0)$ & 0.81 & Gompertz & 14.2 (7.5-21.7) \\
\hline
\end{tabular}

Data in brackets correspond to the $95 \%$ confidence intervals. All data are expressed as milligrams a.i. per kilogram

n.d. not determined, n.t. not tested)

values derived for Mediterranean soils and are in accordance with reproduction data reported by De Silva et al. (2009; NOEC $<0.1$; EC50 of $0.39 \mathrm{mg} / \mathrm{kg}$ ). In opposition, higher toxicity values were reported by Van Gestel et al. (1992; NOEC of 0.6 and EC50 of $2.9 \mathrm{mg} / \mathrm{kg}$ ) and Garcia et al. (2008; NOEC of 0.1 and EC50 of $2.8 \mathrm{mg} / \mathrm{kg}$ ). These dissimilarities could be due to differences between the different batches of OECD as different sources of soil components, especially peat, can limit getting similar artificial soils in different laboratories (Hofman et al. 2009).

With respect to the performance of earthworms in the five Mediterranean soils tested, carbendazim caused a similar toxic effect in the reproduction of $E$. andrei (NOEC $\leq 0.58 \mathrm{mg} / \mathrm{kg}$ and EC50s varying by a factor of 1.6). Consequently, the average EC50s for the two groups of soils were very similar (0.76 vs $0.96 \mathrm{mg} / \mathrm{kg}$, respectively, for groups 1 and 2). The pattern observed for AC50s (values for eight natural soils considered), i.e., higher toxicity observed for soils of group 2 , was not confirmed in reproduction tests (values for five natural soils considered). Neither it was possible to establish possible relationships between carbendazim toxicity $\mathrm{pH}$ plus texture, referred for avoidance tests in Section 4.1.

Therefore, these data suggest that, for this particular endpoint and chemical, the tested range of soil properties did not have a major influence on carbendazim toxicity. However, for this same chemical, the lethal effects observed for Eisenia fetida varied by a factor of 14 in five natural soils, but with a broader range of values for organic matter and textural composition, comparatively with the present study (Liu et al. 2012). However, the relationship between soil properties and toxicity data was not object of statistical analysis in the referred study and lethality endpoints are less sensitive to soil properties than reproduction (Jänsch et al. 2005).

Also, in the present study, a higher toxicity was observed for reproduction tests when compared with avoidance reproduction, in four of five comparisons possible. In previous studies on the effects of pesticides in earthworms, contradictory findings were reported. Indeed, Garcia et al. (2008) and De Silva and Van Gestel (2009) found a lower sensitivity of avoidance tests if compared with reproduction ones. In contrast, the results reported by Hund-Rinke and Wiechering (2001) conferred to avoidance tests a sensitivity within the range of both acute (lethality) and chronic (reproduction) tests.

\subsection{Avoidance behavior of E. crypticus in phenmedipham-contaminated soils}

The enchytraeid avoidance test was originally proposed more than 15 years ago by Achazi et al. (1996). During this period of time, several experiments provided additional information on the test performance, chemical sensitivity, and, therefore, the suitability of this group of organisms to be used in such tests (e.g., Achazi et al. 1999; Schäfer 2001; Amorim et al. 2005a, 2008a, b; Novais et al. 2010; Chelinho et al. 2011). However, no standardized guideline on enchytraeid avoidance behavior has been prepared so far, mainly because of the high variability of the test results found. One cannot exclude that enchytraeids may lack specific chemical receptors and therefore may not be suitable to perform avoidance tests. In the present study, E. crypticus individuals were able to detect the increasing soil contamination, despite the higher variability associated with their response. For all tested soils, the highest phenmedipham toxicity was registered for OECD soil, with the lower AC50 $(14.2 \mathrm{mg} / \mathrm{kg})$. In a similar study with $E$. albidus, the estimated AC50 for phenmedipham in OECD soil was of $252.2 \mathrm{mg} / \mathrm{kg}$ (Amorim et al. 2005a), although this value was extrapolated above the tested concentrations. This low toxicity observed for OECD soil was quite unexpected since it has the highest OM (5.8\%) content, which theoretically could had increased chemical sorption (Autio et al. 2004) and, therefore, decrease toxicity.

The avoidance pattern in $\mathrm{Br}$, It 4 , and Por is difficult to explain, since the highest concentrations tested caused no avoidance while in the reproduction tests the same concentrations caused either a significant decrease in juvenile production (at $27 \mathrm{mg} / \mathrm{kg}$ ) or almost no reproduction (at $81 \mathrm{mg} / \mathrm{kg}$ ). Maybe this herbicide could have caused narcotic effects at higher concentrations, hindering the escape of animals from contaminated soil. Apparently, the narcotic effects of phenmedipham have not been checked so far (European Commission 2004). 

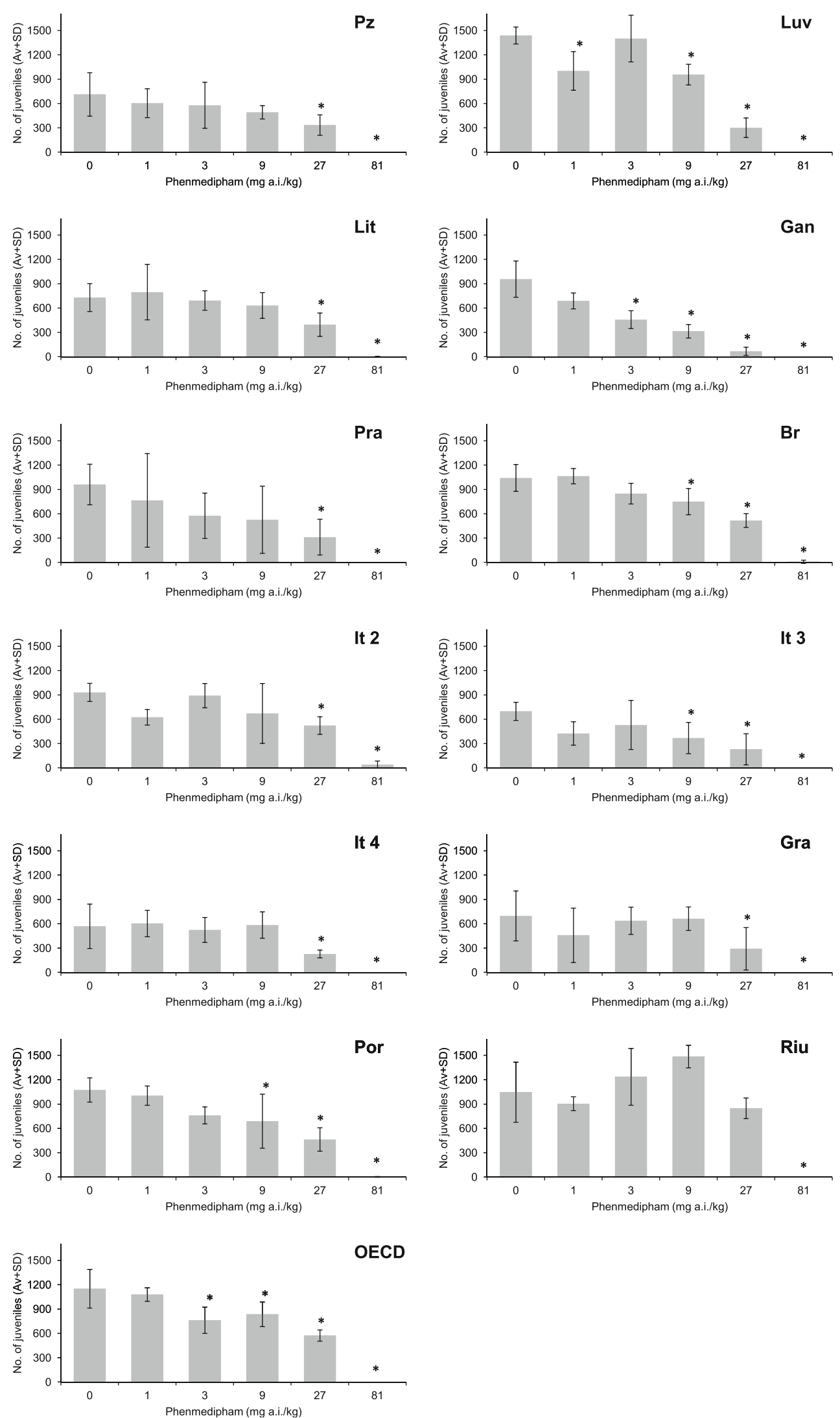

Fig. 5 Effects of Phenmedipham in the reproduction of E. crypticus in 12 Mediterranean soils plus OECD artificial soil. (Results express average number of enchytraeids \pm standard deviation). *significantly lower than control (one-way ANOVA, Dunnett's test, $p<0.05$ ) 
Fig. 6 Average of the derived EC50 (for reproduction tests) and AC50s (for avoidance tests) for the effects of Carbendazim in $E$. andrei (a) and Phenmedipham in E. crypticus (b), using two groups of Mediterranean soils (see Section 2.5.3 and Fig. 1 for more details). $n$ number of cases. AC50 for carbendazim in Gan soil was not included (see Section 2.5.3)

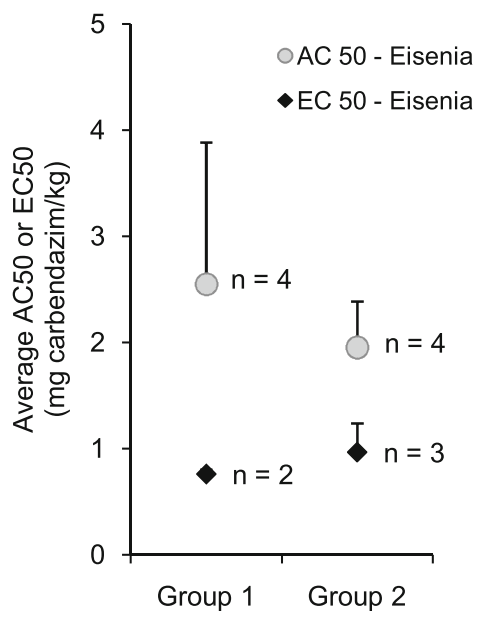

Soil properties did influence phenmedipham toxicity since the sensitivity of enchytraeids (AC50s) varied between $14.2 \mathrm{mg} / \mathrm{kg}$ (for OECD soil) and more than $81 \mathrm{mg} / \mathrm{kg}$ for It2 and It4. The lack of derived AC50s for soils from group 2 was due to the low avoidance response towards the highest phenmedipham concentration $(81 \mathrm{mg} / \mathrm{kg})$ observed for most of the tested soils included there (Br, It 2, It 3, It 4, Gra, and Por). This lower toxicity registered for soils of group 2 may be related with their higher $\mathrm{pH}$, if compared with soil from group 1. In fact, phenmedipham is known to be more susceptible to degradation by chemical hydrolysis, under alkaline conditions (EPA 2005; Roberts et al. 1998). A quicker degradation of this herbicide could therefore explain the low toxicity observed for soils of group 2. In a similar study with E. albidus and several soil types, Amorim et al. (2005a) found no significant relationships between different phenmedipham toxicity and any soil property.

Except for Pz and OECD soils, the derived AC50s for avoidance were higher than those obtained for reproduction. This is also in accordance with previous findings (Amorim et al. 2005a; Novais et al. 2010).

Despite further improvements in E. crypticus avoidance tests are necessary, the available data suggest that the high variability associated to avoidance response is family specific (e.g., Amorim et al. 2005a, 2008b; Novais et al. 2010; Chelinho et al. 2011). This high variability seems to impair the preparation of a test guideline in the near future.

\subsection{Reproduction of E. crypticus \\ in phenmedipham-contaminated soils}

Enchytraeids showed different sensitivity towards 13 phenmedipham-contaminated soils since the EC50s varied between $3.8 \mathrm{mg} / \mathrm{kg}$ in Gan and $32.8 \mathrm{mg} / \mathrm{kg}$ for It 2 (for Riu the EC50 was estimated to be higher than 27 and less than $81 \mathrm{mg} / \mathrm{kg}$ ). The EC50 derived for OECD soil $29.2 \mathrm{mg} / \mathrm{kg}$ was the second highest among 13 tested soils. Using the same substance, Amorim et al. (2005b) derived EC50 values of the same order of magnitude $(34.5 \mathrm{mg} / \mathrm{kg})$ for the reproduction of E. albidus, also in OECD soil. The model that presented the best data fit was the hormetic model. This effect was observed mainly in the first two concentrations (1 and $3 \mathrm{mg} / \mathrm{kg}$ ). Römbke and Moser (2002) reported the same effect for carbendazim in the international ring test for enchytraeids reproduction. Thus, subtoxic concentrations can stimulate reproduction; also in field studies, often an extreme compensation reaction was observed during the recovery phase (Didden and Römbke 2001). As in the avoidance tests, where at lower concentrations, enchytraeids often preferred the contaminated soil, in the reproduction tests with the same soils, equal concentrations caused higher juvenile production. This was generally the case for Luv, Lit, It4, and Gra soils.

With respect to effects of soils properties, the mean of EC50s calculated for the two groups of soils revealed the same patterns (lower toxicity for soils with higher $\mathrm{pH}$ ), described earlier for AC50s (Section 3.4). Indeed, the $\mathrm{pH}$ of soils from group 1 is quite acid, ranging between 4.2 and 4.6, with exception of $\mathrm{Gan}(\mathrm{pH}=7.7)$, However, the lowest EC50 was registered for the last soil $(3.8 \mathrm{mg} / \mathrm{kg})$, an apparent contradiction with its alkaline $\mathrm{pH}$ (7.7). Much probably, in this case, the extremely low organic matter content $(0.6 \%)$ of Gan soil was more important in the determination of phenmedipham toxicity to enchytraeids. The low toxicity observed for OECD soil (which had the highest organic matter content, relatively to Mediterranean soils) can also be related with pesticide sorption to soil organic matter.

Amorim et al. (2005b) used the same chemical and five natural soils (plus OECD soil) to evaluate the reproduction of E. albidus and found a positive association between EC50s and sand content, although not significant. However, using the same data and a stepwise regression analysis, the same authors found that phenmedipham toxicity was significantly decreased at lower values of WHC and higher organic matter contents of soils. 
In summary, the available data suggest that phenmedipham toxicity to E. crypticus was negatively related with soil $\mathrm{pH}$, but extreme values of organic matter may have exerted a stronger influence on the observed responses.

Autio et al. (2004) studied the adsorption of herbicides in different Finnish soils, but no soil parameter could alone explain the degree of phenmedipham adsorption, although the authors referred to organic matter and soil $\mathrm{pH}$ as properties potentially influencing its sorption and degradation. Also, the adsorption strength of phenmedipham was the second highest within five tested herbicides and the coefficient Kfoc calculated for ten soils varied for a factor of 15 , anticipating a soil effect.

\section{Conclusions}

This work intended to be a starting point to improve soil risk assessment in Mediterranean scenarios by obtaining toxicity data in geographically representative soils and ecologically more relevant substrates, if compared with standard artificial OECD soil.

Chemicals caused different effects to both test organisms in different soils. Concerning E. andrei avoidance towards carbendazim-spiked soils, the AC50s varied by between 1.5 and $9.4 \mathrm{mg} / \mathrm{kg}$ and were generally higher for sandy soils with low $\mathrm{pH}$. This influence was not confirmed in reproduction tests, as the derived EC50s were similar in the six tested soils, indicating a low influence of soil properties.

E. crypticus avoidance behavior in phenmedipham-spiked soils was found to be highly variable. Despite this, a higher toxicity was registered for soils with lower $\mathrm{pH}$. In reproduction tests, the EC50s varied by a factor of 9, and phenmedipham toxicity also tended to be increasing in soils with lower $\mathrm{pH}$, except for two soils (Gan and OECD) with extreme organic matter content ( 0.6 and $5.8 \%$, respectively).

Depending on the evaluated endpoint, the values for toxicity of carbendazim or phenmedipham in OECD soil were either similar (reproduction with $E$. andrei), lower (avoidance with $E$. crypticus), or one of the highest (avoidance with $E$. andrei and reproduction with E. crypticus), if compared with Mediterranean soils. Also, this artificial soil did not seem to accurately represent the organic matter content found in Mediterranean soils, neither their textural classes. Thus, OECD soil should be used to assure the quality of the test system itself (i.e., as an "external" control), preferably with reduced organic matter content (5\%) as recently recommended for other OECD test guidelines with soil organisms (OECD 2008).

The results gained here can be used for the normalization of toxicity data in natural soils leading to a more realistic risk assessment. Despite some relationships between soil properties and toxicity were outlined, a clear and statistically significant prediction of chemical toxicity could not be established. As in the present study, the collection of soils was limited to a particular geographical area, the Mediterranean basin, the range of soil properties was probably too narrow to give clearer and more consistent insights on their influence on the observed chemical toxicity. Indeed, the wide range of soil types plus the scarcity of comparable toxicity data in the literature highlight the many unanswered questions on the use of natural soils in ecotoxicological testing. Further research, including other soils, test organisms, and chemical groups/mixtures, is needed to, hopefully, get more consistent answers.

Acknowledgments This study has been funded by Fundação para a Ciência e Tecnologia-Portugal (grant to Sónia Chelinho-SFRH/BM/ 18844/2004) and by CRUP-Acções Integradas Luso-Espanholas (Action nr. E-5/2005), the LODOTOX project of the Spanish Ministry of Science and Technology (AGL2002- 03297). The authors would like to thank the following institutions for the facilities in the Portuguese soils selection/collection: ADPM-Mértola, Companhia das Lezírias, Escola Superior Agrária de Beja, LPN—Liga para a Protecção da Natureza and Universidade de Évora.

\section{References}

Achazi RK, Chroszcz G, Pilz B, Rothe B, Steudel I, Throl C (1996) Der Einfluss des pH-Werts und von PCB52 auf Reproduktion und Besiedlungsaktivität von terrestrischen Enchytraeen in PAK-, PCB- und schwermetallbelasteten Rieselfeldböden. Verh Ges Ö kol 26:37-42

Achazi RK, Fröhlich E, Henneken M, Pilz C (1999) The effect of soil from former irrigation fields and of sewage sludge on dispersal activity and colonizing success of the annelid Enchytraeus crypticus Westheide \& Graefe, 1992 (Enchytraeidae, Oligochaeta). Newsl Enchytraeidae 6:117-126

Amorim MJB, Römbke J, Soares AMVM (2005a) Avoidance behaviour of Enchytraeus albidus: effects of benomyl, carbendazim, phenmedipham and different soil types. Chemosphere 59:501-510

Amorim MJB, Römbke J, Scheffczyk A, Soares AMVM (2005b) Effect of different soil types on the enchytraeids Enchytraeus albidus and Enchytraeus luxuriosus using the herbicide Phenmedipham. Chemosphere 61:1102-1114

Amorim MJB, Römbke J, Schallna $\beta$ H-J, Soares AMVM (2005c) Effect of soil properties and aging on the toxicity of copper for Enchytraeus albidus, Enchytraeus luxuriosus and Folsomia candida. Environ Toxicol Chem 24:1875-1885

Amorim MJB, Rombke J, Scheffczyk A, Nogueira AJA, Soares AMVM (2005d) Effects of different soil types on the collembolans Folsomia candida and Hypogastrura assimilis using the herbicide phenmedipham. Arch Environ Contam Toxicol 49:343-352

Amorim MJB, Novais S, Rombke J, Soares AMVM (2008a) Avoidance test with Enchytraeus albidus (Enchytraeidae): effects of different exposure time and soil properties. Environ Pollut 155:112-116

Amorim MJB, Novais S, Römbke J, Soares AMVM (2008b) Enchytraeus albidus (Enchytraeidae): a test organism in a standardised avoidance test? Effects of different chemical substances. Environ Int 34:363-371

Arias-Estevez M, Lopez-Periago E, Martinez-Carballo E et al (2008) The mobility and degradation of pesticides in soils and the pollution of groundwater resources. Agric Ecosyst Environ 123:247-260

Autio S, Siimes K, Laitinen P et al (2004) Adsorption of sugar beet herbicides to Finnish soils. Chemosphere 55:215-226

Berglöf T, Van Dung T, Kylin H, Nilsson I (2002) Carbendazim sorptiondesorption in Vietnamese soils. Chemosphere 48:267-273 
Breitholtz M, Rudén C, Hansson SO, Bengtsson B-E (2006) Ten challenges for improved ecotoxicological testing in environmental risk assessment. Ecotoxicol Environ Saf 63:324-335

Chelinho S, Domene X, Campana P et al (2011) Improving ecological risk assessment in the Mediterranean area: selection of reference soils and evaluating the influence of soil properties on avoidance and reproduction of two oligochaete species. Environ Toxicol Chem 30:1050-1058

Daam MA, Silva E, Leitão S, Cerejeira MJ (2011) Environmental risk assessment of pesticides in mediterranean portugal: status and research needs. In: Daniels JA (ed) Advances in environmental research, vol 9. Nova Science Publishers, Inc., New York, pp 213-238

De Silva PMCS, Van Gestel CAM (2009) Comparative sensitivity of Eisenia andrei and Perionyx excavatus in earthworm avoidance tests using two soil types in the tropics. Chemosphere 77:1609-1613

De Silva PMCS, Pathiratne A, Van Gestel CAM (2009) Influence of temperature and soil type on the toxicity of three pesticides to Eisenia andrei. Chemosphere 76:1410-1415

Didden W, Römbke J (2001) Enchytraeids as indicator organisms for chemical stress in terrestrial ecosystems. Ecotoxicol Environ Saf 50:25-43

Dios Cancela G, Romero Taboada E, Sanchez-Rasero F (1992) Carbendazim adsorption on montmorillonite, peat and soils. J Soil Sci 43:99-111

Domene X, Colón J, Uras MV et al (2010) Role of soil properties in sewage sludge toxicity to soil collembolans. Soil Biol Biochem 42: $1982-1990$

Domene X, Chelinho S, Campana P et al (2012) Applying a GLM-based approach to model the influence of soil properties on the toxicity of phenmedipham to Folsomia candida. J Soils Sediments 12:888-899

Ellis SR, Hodson ME, Wege P (2007) The influence of different artificial soil types on the acute toxicity of carbendazim to the earthworm Eisenia fetida in laboratory toxicity tests. Eur J Soil Biol 43:S239-S245

Environment Canada (2007) Biological test method: test for measuring survival and reproduction of springtails exposed to contaminants in soil. Environmental Technology Centre, Report EPS 1/RM/47, Environment Canada, Ottawa, Ontario. http://publications.gc.ca/ collections/collection_2012/ec/En49-7-1-47-eng.pdf. Accessed 7 Nov 2013

EPA (2005) Reregistration eligibility decision for phenmedipham, EPA 738-R-05-007 United States Environmental Protection Agency. http://www.epa.gov/oppsrrd1/REDs/phenmedipham red.pdf. Accessed 13 Sept 2013

European Commission (2004) Review report for the active substance phenmedipham. Health \& Consumer Directorate - General. Report SANCO/4060/2001-final. http://ec.europa.eu/comm/food/plant/ protection/evaluation/existactive/list phenmedipham.pdf. Accessed 23 May 2013

European Commission (2005) Soil atlas of Europe, European Soil Bureau Network, Office for Official Publications of the European Communities, L-2995, Luxembourg. http://eusoils.jrc.ec.europa. eu/projects/Soil Atlas/Download.cfm. Accessed 7 Nov 2013

Garcia M, Römbke J, De Brito MT, Scheffczyk A (2008) Effects of three pesticides on the avoidance behavior of earthworms in laboratory tests performed under temperate and tropical conditions. Environ Pollut 153:450-456

Hofman J, Hovorkova I, Machat J (2009) Comparison and characterization of OECD artificial soils. In: Moser H, Roembke J (eds) Ecotoxicological characterisation of waste. Results and experiences from an European ring test. Springer, New York, pp 223-229

Hund-Rinke K, Wiechering H (2001) Earthworm avoidance test for soil assessment. J Soils Sediments 1:15-20

International Organization for Standardization (2004) Soil quality-effects of pollutants on Enchytraeidae (Enchytraeus sp.). Determinations of effects on reproduction and survival. ISO 16387. ISO, Geneva
International Organization for Standardization (2008) Avoidance test for determining the quality of soils and effects of chemicals on behaviour. Part 1: Test with earthworms (Eisenia fetida and Eisenia andrei). ISO 17512. ISO, Geneva

International Organization for Standardization (2012) Soil quality —effects of pollutants on earthworms. Part 2: Determination of effects on reproduction of Eisenia fetida/Eisenia andrei. ISO 11268-2. ISO, Geneva

Jänsch S, Amorim M, Römbke J (2005) Identification of the ecological requirements of important terrestrial ecotoxicological test species. Environ Rev 13:51-83

Kördel W, Römbke J (2001) Requirements on physical, chemical and biological testing methods for estimating the quality of soils and soil substrates. J Soils Sediments 1:98-104

Kördel W, Peijnenburg W, Klein CL et al (2009) The reference-matrix concept applied to chemical testing of soils. Trends Anal Chem 28: $51-63$

Kuhnt G, Vetter L (1999) Field work of EUROSOILS: sampling sites, profile properties and collection procedures. In: Gawlik BM, Muntau H (eds) EUROSOILS II-laboratory reference materials for soil-related studies. European Commission, Luxembourg, pp 41-56 http://bookshop. europa.eu/en/eurosoils-ii-pbCLNA18983/. Accessed 7 Nov 2013

Kuperman RG, Amorim MJB, Römbke J et al (2006) Adaptation of the Enchytraeid toxicity test for use with natural soil types. Eur J Soil Biol 42:S234-S243

Kuperman RG, Checkai RT, Garcia MVB et al (2009) State of the science and the way forward for the ecotoxicological assessment of contaminated land. Pesq Agropec Bras 44:811-824

Liu K, Pan X, Han Y et al (2012) Estimating the toxicity of the weak base carbendazim to the earthworm (Eisenia fetida) using in situ pore water concentrations in different soils. Sci Total Environ 438:26-32

Maliszewska-Kordybach B, Klimkowicz-Pawlas A, Smreczak B (2008) Soil reference materials in ecotoxicity testing - application of the concept of EURO-Soils to soils from Poland. Pol J Environ Stud 17: 257-266, http://www.pjoes.com/pdf/17.2/257-266.pdf

Natal-da-Luz T, Amorim MJB, Römbke J, Sousa JP (2008) Avoidance tests with earthworms and springtails: defining the minimum exposure time to observe a significant response. Ecotoxicol Environ Saf 71:545-551

Novais SC, Soares AMVM, Amorim MJB (2010) Can avoidance in Enchytraeus albidus be used as a screening parameter for pesticides testing? Chemosphere 79:233-237

Organisation for Economic Co-Operation and Development (1984) Guideline for testing of chemicals - earthworm acute toxicity tests. OECD Guideline for the testing of chemicals 207, Paris, France http://www.oecd.org/chemicalsafety/risk-assessment/1948293.pdf. Accessed 7 Nov 2013

Organisation for Economic Co-Operation and Development (2008) Predatory mite (Hypoaspis (Geolaelaps) aculeifer) reproduction test in soil. OECD guideline for the testing of chemicals 226, Paris, France http://www.oecd.org/chemicalsafety/testing/38972970.pdf. Accessed 7 Nov 2013

Paszko T (2012) Effect of pH on the adsorption of carbendazim in Polish mineral soils. Sci Total Environ 435-436:222-229

Peijnenburg WJGM, Baerselman R, Groot AC et al (1999) Relating environmental availability to bioavailability: soil-type-dependent metal accumulation in the Oligochaete Eisenia andrei. Ecotoxicol Environ Saf 44:294-310

Ramos C, Carbonell G, Baudýn JMG, Tarazona JV (2000) Ecological risk assessment of pesticides in the Mediterranean region. The need for crop-specific scenarios. Sci Total Environ 247:269-278

Roberts TR, Hutson DH, Philip WL, Nicholls PH, Plimmer JR (eds) (1998) Metabolic pathways of agrochemicals: herbicides and plant-growth regulators. The Royal Society of Chemistry. Bookcraft, Stroud

Rocheleau S, Kuperman RG, Simini M et al (2010) Toxicity of 2,4dinitrotoluene to terrestrial plants in natural soils. Sci Total Environ 408:3193-3199 
Römbke J, Amorim M (2004) Tackling the heterogeneity of soils in ecotoxicological testing: an EURO-soil based approach. J Soils Sediments 4:276-281

Römbke J, Moser T (2002) Validating the enchytraeid reproduction test: organisation and results of an international ringtest. Chemosphere 46:1117-1140

Römbke J, Jänsch S, Junker T et al (2006) Improvement of the applicability of ecotoxicological tests with earthworms, springtails and plants for the assessment of metals in natural soils. Environ Toxicol Chem 25:776-787

Römbke J, Jänsch S, Junker T et al (2007) The effect of tributyltin-oxide on earthworms, springtails, and plants in artificial and natural soils. Arch Environ Contam Toxicol 52:525-534

Sakuma M (1998) PriProbitNM 1.63. http://www.ars.usda.gov/Services/ docs.htm?docid=11284. Accessed 23 May 2013

Schäfer RK (2001) Evaluation of the ecotoxicological threat of ammunition derived compounds to the habitat function of soil. Ph.D. Dissertation, Freien Universität Berlin, Germany. http:/www.diss.fu-berlin.de/diss/receive/ FUDISS thesis_000000000563. Accessed 7 Nov 2013

Sijm D, Kraaij R, Belfroid A (2000) Bioavailability in soil or sediment: exposure of different organisms and approaches to study it. Environ Pollut 108:113-119

Smit CE, Van Gestel CAM (1998) Effects of soil type, prepercolation, and ageing on bioaccumulation and toxicity of zinc for the springtail Folsomia candida. Environ Toxicol Chem 17:1132-1141
StatSoft Inc (2004) STATISTICA (data analysis software system), version 7.0. www.statsoft.com. Accessed 7 Nov 2013

Stephenson GL, Koper N, Atkinson GF et al (2000) Use of nonlinear regression techniques for describing concentration-response relationships of plant species exposed to contaminated site soils. Environ Toxicol Chem 19:2968-2981

Ter Braak CJF, Smilauer P (2002) CANOCO reference manual and CanoDraw for Windows users guide: software for canonical community ordination (version 4.5). Microcomputer Power, Ithaca

Tibberg E (1998) Nordic reference soils: 1. Characterisation and classification of 13 typical nordic soils; 2 . Sorption of 2,4-D, atrazine and glyphosate. TemaNord 537, Nordic Council of Ministers, Copenhagen

Van Gestel CAM (2012) Soil ecotoxicology: state of the art and future directions. ZooKeys 296(176):275-296

Van Gestel CAM, Weeks JM (2004) Recommendations of the 3rd International Workshop on Earthworm Ecotoxicology, Aarhus, Denmark, August 2001. Ecotoxicol Environ Saf 57: $100-105$

Van Gestel CAM, Breemen EMD-V, Baerselman R et al (1992) Comparison of sublethal and lethal criteria for nine different chemicals in standardized toxicity tests using the earthworm Eisenia andrei. Ecotoxicol Environ Saf 23:206-220

Westheide W, Graefe U (1992) Two new terrestrial Enchytraeus species (Oligochaeta, Annelida). J Nat Hist 26:479-488

Zar JH (1999) Biostatistical analysis. Prentice Hall International, London 